\title{
Los juegos estéticos de la naturaleza en la Edad Media: de la iluminación metafísica del neoplatonismo a la seducción de lo corpóreo del neoaristotelismo
}

\author{
The aesthetic games of the nature in the \\ Middle Ages: from the neoplatonic \\ metaphysical lighting to the neoaristotelian \\ corporeal seduction
}

\author{
Ana María C. MineCAN \\ Universidad Complutense de Madrid \\ aminecan@ucm.es
}

Recibido: 12-04-2016

Aceptado: 30-05-2016

\section{Resumen}

El presente artículo analiza la evolución del papel estético de la naturaleza en la Edad Media desde el punto de vista del influjo que los sistemas filosóficos sobre la interpretación de lo corpóreo como vía legítima hacia el conocimiento la verdad. Analizaremos el enfoque intimista del neoplatonismo y la plasmación de sus premisas en el rechazo por la belleza física y el cambio producido tras la asimilación del aristotelismo hacia una externalización naturalista de los intereses intelectuales y artísticos.

Palabras clave: estética medieval, filosofía, arte, neoplatonismo, aristotelismo.

\section{Abstract}

This article analyzes the evolution of aesthetic role of the nature in the Middle Ages from the point of view of the philosophical systems influence on the interpre- 
tation of the corporal as a legitim way to the knowledge of the truth. It studies the intimate approach of neo-platonism, the shaping of its premises in the rejection of physical beauty and the change that occured after the assimilation of Aristotelianism toward a naturalistic outsourcing of the intellectual and artistic interests.

Keywords: medieval aesthetics, philosophy, art, neo-platonism, aristotelianism.

La visión apresurada que, en muchas casos, se ofrece desde los estudios de filosofía a la época medieval no sólo condena un rico y apasionante periodo del pensamiento humano a los ya ajados tópicos del oscurantismo y la falta de originalidad, sino que ciega cualquier pretensión coherente de comprender las bases mismas del pensamiento ulterior ofreciendo una definición simplificada $y$, con ello, errónea de los mil años anteriores al nacimiento de la Modernidad.

Nuestra perspectiva historiográfica actual sigue estando presa, en lo que respecta a la filosofía medieval, de los prejuicios propiamente modernos ${ }^{1}$ marcados por los ideales de una revolución conceptual que ansiaba la autoafirmación y una nueva libertad para el ser humano ${ }^{2}$. Así, bajo la deslumbrante grandeza de los desarrollos antropocéntricos del humanismo ${ }^{3}$, que fijó su admiración en la producción intelectual de la Antigüedad clásica greco-romana, la Edad Media aparece como un pesado inconveniente cuyo tratamiento tiende a zanjarse con descuido y celeridad. Como consecuencia, el análisis del periodo medieval se pasa por alto en el juego bivalente de comparación entre antiguos y modernos bajo la excusa de que lo ignorado no es más que la escoria, los restos deformes y anquilosados de la gloriosa Atenas.

No obstante, este intento de evasión fracasa en sus aspiraciones de rigor al ignorar diez siglos de historia, diez siglos de preguntas, diez siglos de filosofía. Las centurias olvidadas son, nada menos, que la cuna de muchas de las ideas que vertebraron en pensamiento occidental posterior y, sin las cuales, no es posible comprender ni explicar el desarrollo de la metafísica, la ontología, la política, la ética o la ciencia modernas. La visión, por tanto, del periodo medieval como una etapa susceptible de ser resumida bajo los términos de barbarie, represión y pobreza intelectual no

\footnotetext{
1 Véase al respecto el magnífico estudio de Rodríguez de la Peña, M.A., ¿Media tempestas? Las raíces cristianas de Europa y la Leyenda Negra de la Edad Media”, Traditio Catholica. En torno a las raíces cristianas de Europa, Rodríguez de la Peña, M.A., López Atanes, F., (eds.), CEU Ediciones, Madrid, 2009, pp. 15-44.

2 Cfr. Baura García, E., "El origen del concepto historiográfico de la Edad Media oscura. La labor de Petrarca", Estudios Medievales Hispánicos, n.1, 2012, p.11.

3 Cfr. Maritain, J., Humanismo integral, Ediciones Palabra, Madrid, 2001, pp. 54-60.
} 
es más que "un constructo tiránico"4, "un cadáver historiográfico que se resiste a morir"5.

A lo largo de las próximas páginas nos centraremos en ofrecer una lectura filosófica de algunos aspectos de la estética medieval, que permita deconstruir parcialmente la devaluación excesiva del periodo mostrando de qué forma los sistemas de pensamiento que dominaron la Edad Media dibujaron, en combinación con las premisas de las religiones monoteístas, nuevos caminos especulativos que mantuvieron su vigencia mucho más allá de los límites temporales del medioevo.

\section{La Alta Edad Media}

El primer siglo de la Edad Media estuvo marcado por la caída del sistema político y económico que había sustentado la organización civil de las provincias romanas occidentales. A la disolución del Imperio y el consecuente debilitamiento de las estructuras educativas que daban soporte a la cultura de raigambre griega, se sumó la llegada y expansión de todo un conjunto de formas de espiritualidad oriental entre las cuales el cristianismo y, posteriormente, el Islam lograron una importante modificación en las bases de la reflexión filosófica. Las religiones monoteístas comenzaron a ocupar el protagonismo cultural6, sin que ello supusiera, sin embargo, la aniquilación total de las ideas anteriores que se filtraron en la nueva cosmovisión manteniendo sus formas bajo nuevas interpretaciones. Tanto cristianos como musulmanes asimilaron rápidamente los elementos centrales del discurso racional greco-romano que fueron puestos al servicio de la defensa de sus propias ideas éticas, políticas y estéticas.

El comienzo de la Edad Media fue, por tanto, un periodo de mestizaje y contagio entre el racionalismo filosófico griego y las premisas de la fe. Muy pronto sabios y pensadores, formados en los estudios clásicos, se convirtieron a la nueva religión dando lugar a un conjunto de obras en las cuales el estilo argumentativo dialéctico y los conceptos filosóficos se pusieron al servicio de la defensa de la nueva espiritualidad.

Dios es un ser racional y la razón estaba primero en Él, y de Él se derivó a todas las cosas. Esa razón es el conocimiento que tiene de sí mismo. Los griegos lo llaman $\lambda$ ó que es el término que corresponde al nuestro de sermo. ${ }^{7}$

\footnotetext{
4 Reuter, T., "Medieval, Another Tyrannous Construct?", Medieval History Journal, nº 1, 1998, pp. 25 45.

5 Rodríguez de la Peña, M. A., Los reyes sabios, Ed. Actas, Madrid, 2008, p. 7.

6 Cfr. Teja, R., El cristianismo primitivo en la sociedad romana, Ediciones Istmo, Madrid, 1990, pp. 33- 37.

7 Tetruliano, Tertulians Treatise Agaist Praxeas, edición, traducción y comentario de. E. Evans, Londres, 1948, p. 82 (la traducción al castellano es mía).
} 
Observamos, en esta definición de la divinidad ofrecida por Tertuliano en el siglo III, la incorporación de la terminología griega en el discurso teológico y la insistencia en el carácter racional de Dios -como intelecto que se piensa a sí mismo- propia de todos los pensadores medievales influidos profundamente por la filosofía, frente a las visiones puramente exegéticas en las cuales se subrayaba fundamentalmente su carácter voluntario y omnipotente.

Sin embargo, a pesar de la mezcla producida, desde el punto de vista filosófico, entre las dos culturas, algunos elementos del pasado grecorromano fueron tomados por los cristianos como emblemas de una forma de vida moralmente rechazable. 8 Los gustos, costumbres y principios éticos que regían a los dioses 9 y hombres de la literatura antigua eran, para los nuevos protagonistas de la civilización europea, una sombra que impedía mirar fijamente la luz de un nuevo sol.

Muéstrame, pues, tú a ti mismo: si no eres adúltero, si no eres deshonesto, si no eres invertido, si no eres rapaz, si no eres defraudador, si no te irritas, si no eres envidioso, si no eres arrogante, si no eres altanero, si no riñes, si no amas el dinero, si no desobedeces a tus padres, si no vendes a tus hijos. (...) Pues también sobre ti proyecta todo esto una sombra, como la mota que se mete en el ojo para no poder mirar fijamente la luz del sol. Así también tus impiedades, oh hombre, proyectan sobre ti una sombra, para que no puedas mirar a Dios. 10

Frente al carácter materialista de los griegos -como es el caso de Aristóteles o Epicuro-, en el que la naturaleza y lo corpóreo eran causa de admiración estética, los cristianos de los primeros siglos expulsaron de la exterioridad mundana toda forma de verdad y de belleza. Inspirados por el neoplatonismo11, situaron la belleza suprema fuera del mundo de lo sensible convirtiéndola en una realidad estrictamente trascendental. Con ello, la facultad de alcanzarla fue caracterizada como una

\footnotetext{
8 "Vengamos, pues, también a los griegos, para ver si tienen alguna idea sobre Dios. Ahora bien, los griegos, que dicen ser sabios, se mostraron más necios que los caldeos, introduciendo muchedumbre de dioses que nacieron, unos varones, otros hembras esclavos de todas las pasiones y obradores de toda especie de inquidades; dioses, de quienes ellos mismos contaron haber sido adúlteros y asesinos, iracundos y envidiosos y rencorosos, parricidas y fraticidas, ladrones y rapaces, cojos y jorobados, y hechiceros y locos." Arístides, Apología, traducción Daniel Ruiz Bueno, Padres Apologetas Griegos, Madrid, Biblioteca de Autores Cristianos, 1979. VIII, 1-5.

9 Ejemplo de ello son los ataques de Lactancio al politeísmo y sus esfuerzos por mostrar que los dioses adoradas por griegos y romanos no eran, en realidad, más que simples seres humanos deificados: "No hay nadie tan imprudente que no entienda que aquéllos a los que los inexpertos y necios llaman y adoran como dioses fueron en realidad mortales." Lactancio, Instituciones Divinas (2 vols), traducción de Eustaquio Sánchez Solar, Madrid, Gredos, 1990. I 3, 1.

10 Teófilo de Antioquía, Theophile d'Antiocie. Trois livres à Autolicus. Texte grec établi par G. Bardy, trad. de J. Sender, Sources chrét. no 20, Paris, 1948. p.59, nt.1 (la traducción al castellano es mía).

11 Cfr. Plotino, Enéada tercera, traducción, prólogo y notas José Antonio Miguez, Buenos Aires, Aguilar, 1978. III, 5,2.
} 
introyección solipsista bajo la convicción de que sólo en el alma humana pueden hallarse los ecos de la sabiduría divina. De esta forma, todo lo relativo a lo sensorial y empírico quedó despojado de interés cognitivo. Los objetos del mundo extramental fueron consideradas contingencias secundarias, meros reflejos alegóricos o participaciones de una sustancia absoluta y supraterrenal.

La profundidad (del ser o de la cosa) es la materia, y es porque la materia es tenebrosa. La luz que ilumina es la forma; la inteligencia ve la forma. Viendo la forma en un ser, ella juzga que la profundidad de ese ser es una oscuridad situada debajo de la luz; de la misma manera, el ojo luminoso, dirigiendo su mirada a la luz o a los colores, que son especies de luces, discierne la existencia del fondo oscuro y material escondido bajo la superficie coloreada. ${ }^{12}$

Lo tenebroso, tal como señala Plotino en estas líneas, residía la materia ontológicamente inferior cuyo estatus corporal, temporal y finito alimentaba la despreocupación del sabio por sus cualidades frente al estudio de lo eterno e inmóvil. ${ }^{13}$

Es preciso que el ojo se haga parecido y semejante al objeto visto para aplicarse a contemplarlo. Jamás vería un ojo el sol sin haberse hecho semejante al sol, ni vería un alma lo bello sin ser bella. Que todo ser se torne pues, primero divino y bello si quiere contemplar a Dios y lo bello. ${ }^{14}$

Se contrapusieron así dos visiones, dos tipos de mirada, la del ojo interior capaz de vislumbrar metafóricamente la verdad y la de los ojos del cuerpo condenados a una insuperable y sombría confusión. ${ }^{15}$ Como sostiene Bréhier, la figuración de esta época pretendía constantemente mostrar, no la realidad misma, sino una interpretación de ella que permitiera hacer llegar al espectador lo inteligible de su esencia. ${ }^{16}$ En este sentido, la preocupación por la belleza de los cuerpos, de las vestimentas o de los objetos pasó a ser considerada como un signo del paganismo que debía dejarse atrás. El ascetismo ${ }^{17}$, común en la gran mayoría de religiones orientales, comenzó a imponerse frente al materialismo opulento del que gustaban griegos y romanos. Las representaciones artísticas de los primeros tres siglos de nuestra era dan prueba de ello. Un alto esquematismo simbólico que rehúye de la representación

\footnotetext{
12 Plotino, Enéada segunda, Aguilar, Buenos Aires, 1964. II, 4, 5.

13 Cfr. Grabar, A., Plotin et les origines de l'esthetique médiévale, Macula, Toulouse, 2002, pp. 4046.

14 Plotino, Enéada primera, Aguilar, Buenos Aires, 1963. I, 6,9.

15 Grabar, A., Los orígenes de la estética medieval, Siruela, Madrid, 2007, p. 40.

16 Bréhier, E., The middle ages and the renaissance, Universtity of Chicago Press, Chicago, 1965. p. 29.
}

17 Drukheim, E., Las formas elementales de la vida religiosa, Alianza, Madrid, 2003, pp. 478-480. 
pictórica dominó las producciones cristianas frente a la exhuberancia del estilo romano tardío que seguía produciéndose entre los paganos. Sólo a partir del siglo III comenzó un desarrollo iconográfico en el cual, al igual que ocurre con la filosofía, es posible apreciar la mezcla entre las dos cosmovisiones. ${ }^{18}$ Ejemplo de ello es el modelo del Cristo filósofo en el que Jesús de Nazaret aparece ataviado con túnica corta, al estilo de los maestros romanos, sosteniendo un libro. 19

El mundo de la Alta Edad Media latina fue, por tanto, un escenario en el que la luz y la oscuridad se repartieron de forma definida en los dos ámbitos ontológicos aceptados. La luz alcanzó una dimensión metafísica referida exclusivamente al ámbito espiritual de la divinidad y a la introspección íntima de los sujetos, en una vinculación directa con los procesos racionales dirigidos hacia el conocimiento de un conjunto de verdades que no podían hallarse en la naturaleza.

Sucede que no pueden nuestros ojos contemplar la naturaleza misma de la luz, esto es, la naturaleza del sol, pero al ver su esplendor y sus rayos que se difunden por las ventanas o por cualquier otro sitio donde penetra la luz, podemos imaginar la identidad del principio y la fuente de la luz material. Pues así, las obras de la providencia divina y el arte que se recibe en nuestro universo, vienen a ser como los rayos que emite la naturaleza de Dios. ${ }^{20}$

El valor de lo invisible se exacerbó al considerar la imagen, desde el punto de vista filosófico, como un producto secundario de la acción divina. La plasmación figurativa era, incluso en lo que respecta a la propia divinidad, ontológicamente posterior al pensamiento y la acción verbal de Dios. La imagen era criatura, la palabra que ejecuta el pensamiento, creación.

En este sentido, la sonoridad invisible de la palabra se impuso como vía fundamental para la salvación. ${ }^{21}$ Frente a la claridad de los textos divinos, todo lo visible, desde el punto de vista físico era confuso, desconocido, inquietante e incluso sus-

18 "Es una mitología vuelta contra sí misma: Prometeo y Orfeo representan al padre Creador y a Cristo. Abundan los motivos pastoriles: el Buen Pastor, trasposición del Mercurio Crioforo aparece al lado de figuras orantes en el sarcófago de Moruecos (Museo de Letrán) en medio de amores vendimiadores. Encontramos en la pintura la Historia de Psique, imagen del alma (cementerio de Domitila), escenas de banquetes que disimulan, bajo un aspecto profano, los ágapes eucarísticos (cementerio de Priscila) figuras orantes y bellas formas emblemáticas." Chastel, A., El arte italiano, Ed. Akal, Madrid. 1988. pp. 35-36.

19 Un ejemplo de este motivo puede encontrarse en la escultura del siglo IV que ahora se encuentra en el Museo Nazionale Romano, Palazzo Massimo alle Terme, Roma. Cfr. García Marsilla (dir.) Historia del arte medieval, Publicaciones de la Universitat de València, Valencia, 2012, p. 34.

20 Orígenes, De principiis, Ed. Edad Nueva, Madrid, 2015. pp.132-133.

21 Cfr. Fernández Vallina, E., "Lectura del texto como compañera de la lectura de imágenes en época latina medieval: los momentos didácticos de una analogía", Est hic vera lectio: la lectura en el mundo antiguo, Ediciones Universidad de Salamanca, Salamanca, 2008, pp. 143-166. 
ceptible de llevar a la perdición del alma. Desde este punto de vista, la imagen corporal quedó metafóricamente ligada a la oscuridad en sentido moral y metafísico.

No obstante, tal como advierte $\mathrm{Eco}^{22}$, la insistencia de los rigoristas en los peligros de lo corpóreo muestra que el pensamiento del periodo altomedieval no consistió en una negación de lo sensible, sino más bien en un reconocimiento del enorme poder de seducción de algo bello en grado sumo. Es decir, mientras que los modernos llegaron a poner en cuestión la realidad ontológica de lo físico postulando la posibilidad de que todo lo relativo a este ámbito pueda ser un mero producto de la imaginación o de un razonamiento incorrecto $23,-$-recuperando así la herencia parmenídea que caracterizaba lo natural como falta apariencia sin referente real-, los medievales consideraron el mundo físico tan real como el propio de las sustancias espirituales. Por tanto, no cabe hablar, en el caso del pensamiento medieval, de un antirrealismo. Dicha afirmación chocaría directamente con el dogma de la creación que hablaba de la entrada en el ser de todo lo existente por obra de Dios.

Tampoco se puede sostener que el problema señalado por los medievales estuviera relacionado con el engaño de los sentidos que puede conducir a errores que lleven a tomar por verdadero lo que en realidad no lo es. Los sentidos, para la mentalidad de los pensadores medievales no engañan sino que sobreexcitan, inflaman la curiosidad por los objetos corpóreos externos en los cuales, según las premisas neoplatónicas, sólo se puede hallar un camino aparente hacia la verdad. En este sentido, las realidades naturales eran vías muertas para los filósofos de los primeros siglos en lo que respecta a las aspiraciones espirituales exigidas por el cristianismo $\mathrm{y}$, al mismo tiempo, fuentes inagotables de maravillas y admiración que podían anclar el alma en la observación de lo efímero y pasajero.

Bajo el fuerte influjo del neoplatonismo, la filosofía de Agustín de Hipona se alzó como el canon filosófico principal del cristianismo hasta bien entrado el siglo XIII24. Su teoría epistemológica tuvo como eje principal la metáfora de la luz, esta vez entendida como el canal de comunicación de la verdad por parte de Dios al alma humana. La luz, simbolizaba no sólo la verdad-Dios sino el modo en el que se alcanzaba dicha verdad mediante un proceso de origen externo denominado illuminatio, en el cual al ser humano le correspondía exclusivamente la posición de paciente.

\footnotetext{
22 Eco, U., El arte y la belleza en la estética medieval, Ed. Lumen, Barcelona, 1999, pp. 13-15.

23 "Sin embargo, antes de ahora he recibido y admitido como muy ciertas y muy manifiestas cosas que después he reconocido eran dudosas e inciertas. ¿Cuáles eran, pues, estas cosas? La tierra, el cielo, los astros y todas las otras cosas que percibía por medio de mis sentidos.” Descartes, R., Meditaciones metafisicas, Ed. Alianza, Madrid, 2015, p.79.

24 A partir del siglo XIII, el augustinismo convivió con el aristoelismo tomista que se constituyó como segunda alternativa doctrinal.
} 
Esta voz interior que nos invita a pensar en Dios, a buscarlo, a desearlo sin tibieza, nos viene de la fuente misma de la Verdad. Es un íntimo resplandor en que nos baja el secreto Sol de las almas. De Él procede toda verdad que sale de nuestra boca, aun cuando nuestros ojos, o por débiles o por falta de avenamiento, trepidan al fijarse en él y abrazarlo en su integridad. 25

En el nimbo crucífero que ilumina la cabeza del Pantocrátor de la abadía de Prüm ${ }^{26}$ puede leerse "lex, pax, lux". ${ }^{27}$ Estos tres términos condensan el pensamiento agustiniano según el cual el sosiego y la paz del alma sólo se pueden alcanzar escuchando la verdad de la ley divina que ilumina el alma humana.

Junto a la pintura, la arquitectura románica reflejó con fuerza todos estos ideales. Los gruesos muros y contrafuertes de las iglesias, monasterios y abadías, aislaban a monjes y clérigos no sólo de las distracciones del mundo urbano sino también de la atracción sensual de una naturaleza exuberante, salvaje, desconocida e incontrolable. Al igual que el cuerpo humano, para el neoplatonismo, era aquello que impedía la absoluta comunión con Dios, el propio cuerpo del edificio, pesado, asfixiante y carente de vanos limitaba hasta el extremo la llegada de la luz exterior. En la oscuridad, el estudio y el desarrollo de la vida era posibilitado por la iluminación artificial, es decir, por el esfuerzo incesante del hombre por hacer luz en lo más oscuro y profundo de su intimidad, al resguardo de las tentaciones naturales.

En este contexto, la condena de las superfluitates de Bernardo de Claraval, cuyo ideario no sólo marcó la filosofía de su orden monacal sino el estilo arquitectónico del románico cisterciense, aglutinó gran parte de las ideas agustinianas adelantando algunas de las tendencias que comenzaron a eclosionar en la Baja Edad Media.

Quedan cubiertas de oro las reliquias y deslúmbranse los ojos, pero se abren los bolsillos. Se exhiben preciosas imágenes de un santo o de una santa, y creen los fieles que es más poderoso cuanto más sobrecargado esté de policromía. Se agolpan los hombres para besarlo, les invitan a depositar su ofrenda, se quedan pasmados por el arte, pero salen sin admirar su santidad. No cuelgan de las paredes simples coronas, sino grandes ruedas cuajadas de pedrerías, rodeadas de lámparas rutilantes por su luz y por sus ricas piedras engarzadas. Y podemos contemplar también verdaderos árboles de bronce, que se levantan en forma de inmensos candelabros, trabajados en delicados filigranas, refulgentes por sus numerosos cirios y piedras preciosas. ${ }^{28}$

\footnotetext{
25 Agustín de Hipona, Del orden, Editorial Católica, Madrid, 1950, p. 273.

26 Monasterio benedictino construido por los francos en torno al siglo VIII.

27 Cfr. Puigarnau, Alfons, "Neoplatonismo e iconografía en la Europa Medieval", Anuario Filosófico, 33, 200, p. 658.

28 Bernardo de Claraval, Obras completas del doctorde Jaime Pons y Rafael Casulleras, Barcelona, 1929. Apología al Abad Guillermo, cap. 29.
} 
Este texto muestra la vinculación que Bernardo encontró entre la sofisticación artística y aquéllas perversiones que los primeros cristianos denunciaban respecto de paganos de los que querían distinguirse. Los templos, al adornarse con pinturas y joyas perdían, para Bernardo, su capacidad de provocar el recogimiento interior, distrayendo a los hombres por medio de la belleza visual de los deberes íntimos a los que debe dedicarse el verdadero creyente. La sofisticación simbólica y estilística de las imágenes constituía una posibilidad para la blasfemia y un camino hacia la idolatría que surgía de la confusión de la belleza artística de un objeto material con el verdadero origen de toda verdad, de todo bien y de toda belleza.

Pero en los capiteles de los claustros, donde los hermanos hacen su lectura, ¿qué razón de ser tienen tantos monstruos ridículos, tanta belleza deforme y tanta deformidad artística? Esos monos inmundos, esos fieros leones, esos horribles centauros, esas representaciones y carátulas con cuerpos de animal y caras de hombres, esos tigres con pintas, esos soldados combatiendo, esos cazadores con bocinas... Podrás también encontrar muchos cuerpos humanos colgados de una sola cabeza, y un solo tronco para varias cabezas. Aquí un cuadrúpedo con cola de serpiente, allí un pez con cabeza de cuadrúpedo, o una bestia con delanteros de caballo y sus cuartos traseros de cabra montaraz. $\mathrm{O}$ aquel otro bicho con cuernos en la cabeza y forma de caballo en la otra mitad de su cuerpo. Por todas partes aparece tan grande y prodigiosa variedad de los más diversos caprichos, que a los monjes más les agrada leer en los mármoles que en los códices, y pasarse todo el día admirando tanto detalle sin meditar en la ley de Dios. ${ }^{29}$

La intensa mezcla de la simbología clásica y cristiana se revela en esta hermosa definición de Bernardo de los capiteles románicos. Junto a las imágenes del Evangelio proliferan monstruos quiméricos, grotescos animales exóticos ${ }^{30} \mathrm{y}$ criaturas mitológicas ${ }^{31}$ que distraían la atención de los monjes. Esta fascinación por los rastros del pensamiento antiguo, como veremos más adelante, fue una de las características fundamentales de los últimos dos siglos de la Edad Media en los cuales, la filosofía griega transformó el pensamiento cristiano dando lugar a una nueva cosmovisión.

\section{La Baja Edad Media}

Los siglos finales de la Edad Media significaron un cambio radical en la visión del hombre, la naturaleza y el tipo de relación que debía establecerse entre ambos.

\footnotetext{
29 Op. cit. Bernardo de Claraval, Obras completas del doctor cap. 29.

30 Cfr. Blázquez, J.M, Arte y religión en el Mediterráneo antiguo, Cátedra, Madrid, 2009, pp. 198-200.

31 Cfr. Jurgis, Baltrusaitis, La Edad Media Fantástica, antigüedades y exotismos en el arte gótico, Cátedra, Madrid, 1983, pp. 165-172.
} 
Todo un conjunto de acontecimientos se sumaron para dar lugar a un cambio radical consistente, desde el punto de vista filosófico, en una exteriorización naturalista de la atención intelectual. Birlanga subraya, al respecto, el efecto estético de tales cambios:

El final del Medievo (...) va separando las dos realidades, no hay lugar ya para la coexistencia de lo armónico con lo inarmónico, de la luz con la oscuridad. Ahora, la atención se centrará en retomar el equilibro entre la belleza sensible (y sensual) con la belleza inteligible (y trascendental), pero ya no de la fealdad que, de esta manera, acabará relegada al margen y a los espacios marginales de la representación, ahora desproporcionada. Pero, al mismo tiempo, se abre un espacio nuevo para el sensualismo de la luz y de la proporción. Si se ha de hacer conciliable la belleza trascendental con la belleza sensible, necesariamente la belleza ha de ser susceptible de afectar tanto al alma como al cuerpo y ello pasa ahora a expresarse de forma más nítida con el tratamiento de la luz y del color. ${ }^{32}$

A partir del siglo XII, y como consecuencia de la recuperación y traducción del inmenso legado filosófico conservado por los árabes - gracias al cual se pudieron volver a conocer, entre muchos otros textos, las obras doxográficas que atesoraban el pensamiento de los presocráticos, algunos diálogos de Platón ${ }^{33}$ y casi la totalidad del corpus aristotélico- la Europa latina se enfrentó a una nueva realidad cultural que estremeció las bases de la tradición neoplatónica anterior.

No obstante, todos estos conocimientos no habrían contribuido a la creación de un nuevo ambiente intelectual si no se hubieran creado unas instituciones educativas que permitieran su estudio y asimilación: las escuelas catedralicias y, posteriormente las universidades.

Precedidas por los centros monásticos y parroquiales en los que se ofrecía una educación elemental, las escuelas catedralicias estuvieron a cargo de los obispados que nombraban a los cancilleres encargados de su dirección. Uno de los elementos capitales para la difusión del saber fue la expedición de las licencias de estudio -licentia docendi- que permitían a los alumnos formados enseñar, primero en el

\footnotetext{
32 Birlanga Trigueros, J.G., "Los márgenes sensualistas de la estética medieval", Montera Arias, I., Muñoz Martínez, A.B., y Villaseñor Sebastián, F., (eds.) Relegados al margen: marginalidad y espacios marginales en la cultura medieval, CSIC, Madrid, 2009, p. 147.

33 Es necesario subrayar el hecho de que si bien la Edad Media estuvo marcada por una orientación platónica en lo que respecta a la filosofía y a la teología, el influjo del propio Platón fue muy escaso ya que sus textos fueron apenas conocidos por los cristianos latinos, a excepción de algunas traducciones del Timeo. En este sentido, aquello que denominamos "platonismo medieval" no es sino el fruto de la interpretación llevada a cabo por los Padres de la Iglesia, entre los cuales destaca Agustín de Hipona. No fue hasta el siglo XV cuando Marsilio Ficino realizó la primera traducción completa al latín de las obras de Platón.
} 
área de la diócesis y más tarde, gracias a la licentia docendi ubique, en cualquier lugar de Europa. 34

En los primeros momentos sólo las catedrales más importantes contaban con escuelas bien nutridas de profesores y materiales. A partir del siglo XII la tendencia se generalizó hasta el punto de que la mayor parte de las catedrales estaban en condiciones de instruir en los principios teológicos a los interesados en la carrera eclesiástica. Estas escuelas abrieron posteriormente sus puestas a los burgueses que exigían enseñanzas no estrictamente religiosas. $35 \mathrm{La}$ importancia de la formación empezó a tomar un sesgo de gran altura en el momento en el que muchos municipios e incluso las cortes regias inauguraron escuelas de corte laico o secular.

Consciente de la importancia creciente de la educación, el papa Alejandro III reguló la enseñanza en las instituciones eclesiásticas mediante un mandato recogido en el Concilio Lateranense III de 1179:

En cada iglesia catedral deberá existir un beneficio suficiente que se asignará a un maestro, el cual se encargará de la enseñanza gratuita de los clérigos de esa iglesia y de los escolares pobres; de esta manera el maestro verá cómo se solucionan las necesidades de la vida y los discípulos verán abrirse ante ellos el camino de la sabiduría. En las otras iglesias y monasterios se destinará nuevamente a este cometido lo que en tiempos pasados hubiera podido dedicarse al mismo. No se exigirá nada por la obtención del permiso de enseñar; ni se podrá cobrar cuota alguna, bajo pretexto de una costumbre existente, a aquellos que enseñan; no se podrá negar para enseñar a quien lo solicite, si es reconocido capaz de este requisito. Quien intentara obrar de manera distinta a lo aquí expuesto, será excluido de todo beneficio eclesiástico. En realidad no es justo privar del fruto de sus esfuerzos en la Iglesia de Dios a aquel cuya avaricia supone un obstáculo a la promoción de las iglesias, al poner en venta el permiso de enseñar. ${ }^{36}$

El impulso otorgado a la cultura occidental por las escuelas catedralicias fue, sin embargo, tan sólo un antecedente discreto de lo que iban a ofrecer a la construcción del pensamiento europeo los siglos finales de la Edad Media. ${ }^{37}$

Surgidas de la organización de los maestros y estudiantes en corporaciones o ligas, las universidades medievales se transformaron en el centro neurálgico del pensamiento filosófico. El fenómeno más destacado de estas nuevas instituciones

\footnotetext{
34 Gómez Oyarzún, Galo, La universidad a través del tiempo, Universidad Iberoamericana, México, 1998, p.21.

35 Fernández Conde, F.J., La religiosidad medieval en España: Plena Edad media (ss. XI-XIII), Piedras Angulares, Universidad de Oviedo, 2000, p.234.

36 Foreville, R., Lateranense I, II, y III. Eset, Vitoria, 1972, pp. 275-276.

37 Véase el completo estudio acerca del nacimiento de las universidades de Rashdall, Hastings, The Universities of Europe in the Middle Ages, ed. Powicke, F.M. y Emden A.B., 3 vols., Claredon Press, Oxford, 1936.
} 
fue su lucha constante por alcanzar la libertad y la autonomía mediante numerosas huelgas y enfrentamientos. Los frutos de esta insistencia se dejaron ver en el logro de un régimen de elevada autonomía tanto respecto a la jurisdicción temporal como a la de los obispos. Bascuñán señala que fue precisamente este nivel de independencia frente al poder civil el que posibilitó que las universidades fuesen las instituciones más idóneas para el desarrollo del diálogo intelectual libre. 38

La aparición de las universidades -como afirma Llorente Díaz ${ }^{39}$-permitió asimismo la fragmentación y la especialización de los estudios, proceso por el cual las ciencias comenzaron una expansión arbórea que anticipó el camino hacia la Modernidad. Entre las más antiguas universidades medievales destacan la de Bolonia, París, Oxford y Montpellier. Todas ellas asimilaron, en distintos aspectos, los nuevos conocimientos y protagonizaron la revolución intelectual de la Baja Edad Media.

Sin acta de fundación conocida, el centro de las principales controversias filosóficas del siglo XIII, la Universidad de Paris, se desarrolló a partir de las escuela catedralicia de Nôtre-Dame. Entre los años 1170 y 1175 los estudiantes comenzaron a aglutinarse en torno al studium de Paris y, hacia el 1180, apareció una forma de organización universitaria rudimentaria, el llamado Collège de Dix-Huit. En una fecha indeterminada, seguramente a finales del siglo XII, la institución adquirió la licencia de studium generale, hecho que la convirtió en foco de atracción de estudiantes de toda Europa. En torno al 1200-1208 la Universidad de París ya estaba establecida tomando el nombre de Universitas magistrorum et scholarium Parisius commoratium. 40

En este nuevo contexto educativo se produjo la recepción del legado naturalista griego. La llegada de los textos de Aristóteles, cuya filosofía era desconocida por los cristianos medievales -a excepción de los dos tratados incluidos en la llamada logica vetus: Categorías y De Interpretatione -provocó un rápido e intenso proceso de modificación en las bases filosóficas occidentales en el cual es posible distinguir tres fases fundamentales.

La primera, comprendida entre 1200 y 1210 , destaca por la actitud eminentemente positiva de las autoridades eclesiásticas y académicas respecto al enriquecimiento que podía aportar el conocimiento de las obras de los antiguos. Ejemplo de ello es la exhortación, en 1205, del Papa Inocencio III a los maestros y alumnos de París para que fueran a Grecia con el fin de reavivar el nuevo saber en la tierra

\footnotetext{
38 Bascuñán, Carlos, Iglesia y universidad, Thaurus, Chile, 1994, p.34.

${ }^{39}$ Llorente Díaz, Marta, El saber de la arquitectura y de las artes. La formación de un ámbito de conocimiento desde la Antigüedad hasta el siglo XVII, Ediciones de la Universidad Politécnica de Cataluña, Barcelona, 2000, p.100.

40 Iyanga Pendi, Augusto, Historia de la Universidad en Europa, Universidad de Valencia, Valencia, 2000, p. 77.
} 
donde nació. ${ }^{41}$ Sin embargo, a pesar de la esperanzada acogida del Papa, la entrada de los textos en la Universidad de París dio origen a una segunda etapa, comprendida entre 1210 y 1245, consistente en un enfrentamiento directo entre la Facultad de Artes y la Facultad de Teología por la libertad de leer las obras de filosofía, especialmente, las de Aristóteles. Este periodo se ejemplifica en la ininterrumpida sucesión de condenas promulgadas en la primera mitad del siglo XIII, como la dictada por el arzobispo de la provincia de Sens y el obispo de París en $1210^{42}$, la promulgada por Roberto de Courçon en 121543, las misivas del Papa Gregorio IX de 122844 y 123045 o el decreto de 1245 por el cual el Papa Inocencio IV tuvo que

41 "Inocencio III a los maestros y escolares de París, con la intención de que, con la invitación del emperador de los griegos, no se arrepientan de ir a Constantinopla para reformar el estudio de letras. A todos los maestros y escolares de París. En muchos lugares y de muchos modos la divina clemencia nos anima a que protejamos la vida del sueño de la muerte y, del lago de la miseria, tomemos aliento en la esperanza de la gloria eterna. Puesto que en verdad nos regocijamos y con razón toda la Iglesia de los santos debe regocijarse de que oriente, al vernos, nos visitara desde lejos, puesto que gran parte de la Iglesia oriental, sin duda casi toda Grecia, que muchísimo tiempo atrás había desdeñado seguir los pasos de su madre la Santa Iglesia Romana, en nuestra época se ha convertido en obediente desde la desobediencia y en devota desde el desprecio. Además, para mayor alegría el muy cristiano y queridísimo para Cristo, nuestro hijo el ilustre emperador de Constantinopla, Balduino, cuida de todos los hombres y los dirije a ella y trbaja con apasionado esfuerzo y preocupación diligente, porque puede y debe propagar la religión cristiana, de manera que el edificio ya construido en gran parte no se derrumbe. Pues en verdad recientemente, dada a conocer la devoción plantada en su pecho en ramas de buena obra de caridad cristiana, nos suplicó humildemente que nos dignáramos a induciros y aconsejaros con cartas apostólicas, a que, yendo a Grecia, os dediquéis a reformar el estudio de letras allí donde tuvieron su comienzo" Denifle; Châtelain, Chartularium Universitatis Parisiensis, París, Delalain, 1889. I, p.62, n⿳3 (la traducción es mía).

42 "Que los Quaternuli del Maestro David de Dinant sean llevados antes de Navidad al obispo de París y que sean quemados, ni los libros de filosofía natural de Aristóteles ni los comentarios (de estos libros) sean leídos en Paris en público o en secreto, y esto lo prohibimos bajo pena de excomunión. Aquellos a los que se encuentre con los Quaternuli del maestro de David de Dinant de navidad en adelante serán tenidos por herejes.” Ib. I, p. 70, nº 11 (la traducción es mía).

43 "Que no sean leídos los libros de Aristóteles sobre Metafísica o sobre filosofía natural ni los Summas sobre los mismos, o sobre la doctrina del maestro David de Dinant, ni del hereje Amaurí, ni sobre Mauricio Hispano.” Ib. I, p.78, nº 20 (la traducción es mía).

44 "Gregorio IX advierte a los maestros en teología regentes en París de que no se inclinen hacia la ciencia mundana y no adulteren la palabra de Dios con las ficciones de los filósofos. A los maestros en teología regentes en París. (...) Así pues, para que el dogma temerario y perverso como un cáncer no repte cual serpiente ni infecte a muchos, y para que no sea necesario que Raquel llore a sus hijos perdidos, por la autoridad de los presentes os encomendamos y aconsejamos severamente que por la sinrazón rechazada profundamente, de la que ya se ha hablado, enseñéis la pureza teológica sin el fermento mundano de la ciencia, sin adulterar la palabra de Dios con las ficciones de los filósofos." Ib. I, p. $114, n^{\circ} 59$.

45 "Gregorio IX en una carta dirigida a los maestros y escolares de París prescribe los estatutos que han de ser cumplidos por el canciller y por ellos mismos tanto en la licencia que se concede como en otras cuestiones. Asigna los libros que han de ser leídos por los que se dedican a las artes e instituye la norma que ha de ser seguida por los estudiantes en la facultad de teología. (...) Además mandamos, 
señalar explícitamente que las restricciones de París debían ser obedecidas por todas las Universidades, ya que Toulouse había ofrecido la lectura libre. 46

La última etapa, comprendida entre 1245 y 1277 aglutina las medidas más agresivas en contra de la lectura de los textos greco-árabes recuperados. Junto a las prohibiciones eclesiásticas, destacan varios hechos importantes como la imposición, por parte de la nación inglesa de la Facultad de Artes y en contra de las condenas papales, en 1252 de la obligación de acudir al menos a un curso sobre el $D e$ Anima, y la promulgación el 19 de marzo de 1255 de la Facultad de Artes en su conjunto de un reglamento propio que decretaba como lecturas obligatorias la Física, el Acerca del Cielo y los Meteorológicos. ${ }^{47}$ Los siguientes años trajeron una agresiva reacción eclesiástica que comenzó el 10 de diciembre de 1270 cuando el nuevo obispo de París, Esteban Tempier condenó bajo pena de excomunión trece proposiciones filosóficas, entre las cuales, muchas tenían una clara inspiración aristotélica. 48 Finalmente, el 7 de marzo de 1277 se produjo la mayor condena filosófica de la Edad Media, en la que fueron prohibidas 219 tesis entre las cuales la referencia a doctrinas y teorías aristotélicas relativas a cuestiones naturales abarca el 20\%.49

Todos estos acontecimientos nos obligan a afirmar que lo que se inició en el campo de la filosofía y la estética a partir del siglo XII fue una inversión de la situación anterior en la cual comenzó a abandonarse la preocupación intimista del cristianismo neoplatonizante, para dar lugar a una nueva tradición defensora de la idea

que los maestros de las artes lean una lección de Prisciano y siempre una después de otra en orden, y respecto a los libros naturales, que fueron prohibidos en el concilio provincial por una causa cierta, que no sean utilizados en París hasta que sean examinados y purgados de toda sospecha de errores." Ib. I, 136, $\mathrm{n}^{\circ} 79$.

46 "Aquellos que desean examinar con más detalle el seno de la naturaleza pudieron allí escuchar (lecturas) acerca de los libros naturales que fueron prohibidos en París.” Ib. I, p.184, nº147 (la traducción es mía).

47 "Año del Señor 1254. Hacemos saber a todo el mundo que todos y cada uno de los maestros de artes de común acuerdo y sin ninguna contradicción, (...) establecemos y ordenamos que todos y cada uno de los maestros de nuestra facultad impongan estos para lograr la licencia: La lógica antigua, es decir el libro de los Predicamentos de Porfirio, Perihermeias, Sobre las divisiones y los Tópicos de Boecio, (...) los mayores y menores de Prisciano, Tópicos y Elencos (sofísticos), Analíticos Primeros y Analíticos Posteriores (...) En cuanto a los IV libros de la Ética (...) los tres libros pequeños, a saber Los seis principios, Barbarismos, De accentu de Prisciano (...) Física de Aristóteles, Metafísica y Libro acerca de los animales (...) libro Acerca del cielo y el mundo, primer libro de los Meteorológicos (...) libro Acerca del alma (...) libro De la generación (...) Libro sobre las causas (...) Libro sobre el sentido y la sensación (...) libro Sobre el sueño y la vigilia (...) libro Sobre las plantas (...) libro Sobre la memoria y el recuerdo (...) libro Sobre la diferencia del espíritu y el alma (...) libro Sobre la muerte y la vida.” Ib., I, p. 228, nº 201 (la traducción es mía).

48 "4. Todo lo que pasa en el mundo inferior está sometido a la acción necesaria de los cuerpos celestes.5. El mundo es eterno.6. Nunca ha habido un primer hombre.13. Dios no puede dar la inmortalidad a una cosa mortal ni la incorrupción a una cosa corruptible Ib. I, pp. 486-487 n. ${ }^{\circ} 432$ (la traducción es mía)

49 Ib. I, p. $543, n^{\circ} 473$. 
de que la naturaleza posee en sí misma y por sí misma un grado de verdad y belleza que la convierten el objeto legítimo de estudio y admiración. Teología y filosofía comenzaron a separarse tomando, cada una de ellas, caminos diferentes gracias a los cuales la naturaleza comenzó a liberarse de la oscuridad a la que había sido condenada por el neoplatonismo.

El hombre nace gracias a la Naturaleza y renace gracias a Dios. La naturaleza no tiene que ver con la teología. Las enseñanzas de ambas no son opuestas sino distintas. 50

La explicación del gótico, por tanto, como expresión artística propia de los dos siglos finales de la Edad Media ha de apoyarse también en las premisas filosóficas que lo animaron. Tal como señala Camille, las dos formas tradicionales de interpretar este estilo - la visión racionalista que enfatiza el aspecto tecnológico de Eugène Emmanuel Viollet-le-Duc ${ }^{51}$ y el enfoque simbólico literario de Emile Mâle52 - adolecen, a pesar de su validez, de una excesiva focalización en los aspectos técnicos y religiosos de este arte, sin atender a otros influjos conceptuales, entre los cuales el papel de la filosofía ha sido descuidado por contraste con el peso que sí se le otorga a la hora de explicar el arte de la Alta Edad Media. El error, a nuestro entender, radica en generalizar y ofrecer una visión homogénea de la totalidad del pensamiento medieval sin advertir que el naturalismo creciente del arte tardomedieval fue acompañado por un proceso paralelo y dotado de los mismos contenidos en el ámbito de la filosofía.

Cuando los hombres de finales del siglo XIII miraban a su alrededor situados en la nave central de la catedral de Amiens, no buscaban ni etiquetar los elementos arquitectónicos ni descifrar los símbolos. Eran los testigos embelesados de una nueva forma de mirar. 53

La nueva "forma de mirar" a la que se refiere Camille fue fraguándose, desde el punto de vista filosófico, a lo largo de más de un siglo de modificaciones a nivel teórico que alteraron de modo significativo la visión de la naturaleza. El primer paso hacia una mayor relevancia del ámbito de lo estético y lo sensorial lo representó la Escuela de Chartres caracterizada por una orientación filosófica fundamentalmente platónica 54 en el sentido estricto del término ya que, en contraposición a la mayoría de pensadores medievales que asimilaron el platonismo a través de San

\footnotetext{
50 Alain de Lille, De planctu naturae. (The Complaint of Nature), trad. Douglas M. Moffat, Archon Books, Hamdem, 1972. I. p. 175 (la traducción al castellano es mía).

51 Cfr. Viollet-le-Duc, E.E., Encyclopedie medievale, Tome 1, Architecture, Heimdal, Paris, 1978.

52 Cfr. Mâle, E., El gótico: la iconografía de la Edad Media y sus fuentes, Encuentro, Madrid, 1986.

53 Camile, M., Arte gótico: visiones gloriosas, Akal, Madrid, 2005, p.12.

${ }^{54}$ Lemay, H.R., "Platonism in the Twelfth-Century School of Chartres", Acta: Center of Medieval and Early Renaissance Studies, 2, 1975, pp. 45-52.
} 
Agustín, los miembros de la escuela de Chartres trabajaron directamente con el Timeo de Platón. Su posición teórica resulta especialmente interesante debido a la reivindicación que tuvo en esta escuela la belleza y la racionalidad armónica55 de la naturaleza creada. Los principales integrantes de la escuela ${ }^{56}$ consideraron que el Creador había construido el mundo según las proporciones matemáticas de las cuales emana su belleza. De ello surgió y se popularizó una nueva visión de Dios como artista.

Dios, como distinguido arquitecto del mundo, como cincelador de la forja áurea, como artífice del maravilloso trabajo artístico, como obrero autor de la admirable obra, construyó el real palacio del mundo de admirable belleza. ${ }^{57}$

La obra divina, es decir, la naturaleza en su conjunto debía de ser tenida por buena y bella. Como ejemplar primero de la acción divina la contemplación de la naturaleza no puede llevar a la perversión del alma cristiana sino que debe constituir un camino, al menos, tan válido como el de la introspección para alcanzar la verdad.

En las obras de los pensadores de Chartres podemos encontrar, por primera vez, la idea -que tanta fortuna habría de encontrar posteriormente en la Modernidad-, según la cual el mundo físico ha de ser tenido como un gran libro en el que se hallan contenidas no las palabras sino las imágenes, las formas y los cuerpos que permiten conocer la potencia de la acción divina. En este sentido, la naturaleza exterior iluminada por la luz física y contemplada por los ojos corporales comenzó a ser considerada como una vía legítima para el interés científico y el goce sensorial bajo la convicción de que había tanta verdad por descubrir y experimentar en la naturaleza como en la propia palabra de Dios contenida en las Escrituras.

Si bien, el papel de los integrantes de la Escuela de Chartres tuvo un enorme peso en el proceso de reivindicación de los aspectos sensoriales y estéticos del mundo físico, el optimismo de corte materialista contenido en los tratados de

55 Cfr. Raña Dafonte, César, "La vida cotidiana en el siglo XII y la reflexión ética de Pedro Abelardo", Agís Villaverde, M., Baliñas Fernández, C., (eds) Pensar la vida cotidiana. Actas III Encuentros Internacionales de Filosofía en el Camino de Santiago, 1997, Publicacións Universidade de Santiago de Compostela, Santiago de Compostela, 2001, p. 126.

56 Para Guillermo de Conches, por ejemplo, existía una distinción entre la actividad creadora de la divinidad y las acciones propias de la naturaleza. Se diferenciaban, por tanto, las operaciones que Dios llevó a cabo sin concurso de ninguna otra cosa -como la creación-y aquellas que se desarrollan en el mundo físico. Esta posición conllevaba el reconocimiento de la perfección de los seres creados a los que la divinidad les ha otorgado una naturaleza capaz de obrar por si misma. Cfr. Guillermo de Conches, Glosae super Platonem, texto crítico e introducción Jeauneau, E., Librairie Philosophique J.Vrin, Paris, 1965, pp.65-69.

57 Op. cit. Alain de Lille, De planctu naturae, p. 22. 
Aristóteles constituyó un punto de inflexión fundamental en el abandono de la mirada agustiniana, dando lugar a una nueva forma de simbiosis entre el pensamiento cristiano y la herencia naturalista aristotélica. Tal como señala Delmar, el hombre descubrió, a lo largo del siglo XIII, una nueva manera de concebir la naturaleza, bajo su forma directa y sensible que sobrepasó el ámbito de la experiencia personal hacia el sentimiento de lo público y comunitario. 58

Una de las figuras que mejor representó, a nivel filosófico, esta transformación conceptual fue Tomás de Aquino, titular de la cátedra dominica de teología de la Universidad de París y principal artífice de la asimilación cristiana del aristotelismo. En su obra podemos observar la ruptura de la división platónica radical entre dos órdenes de realidad dotados de distinta dignidad ontológica.

Todo ser es bueno, en la medida en que es ser. Todo ser, en cuanto tal, está en acto y es de algún modo perfecto, porque todo acto es una perfección. Pues bien, lo perfecto tiene razón de apetecible y de buen, según hemos dicho, y, por consiguiente, todo ser, en cuanto tal es bueno. 59

Para el Aquinate todo lo existente es bueno. En este sentido, no puede ya diferenciarse -a pesar del reconocimiento de una efectiva diversidad entitativa en la naturaleza- entre un mundo espiritual que lleva a la salvación del alma y un mundo físico que puede conducir a su perdición. Todo lo creado por la divinidad constituye un orden necesario que, en conjunto, es belleza.

Una segunda idea fundamental de su reflexión es el hecho de que el conocimiento o la visión directa de la esencia divina no es alcanzable por el ser humano en esta vida. ${ }^{60}$ Es decir, la introspección neoplatónica no conduce al ser humano a la esencia de Dios ni le permite, mediante la anulación de sus sentidos, aprender más de lo revelado en las Escrituras. 61

Según Dionisio cuando en la Escritura se dice de alguien que vio a Dios, se ha de entender que percibió alguna figura sensible o imaginaria que por semejanza representaba algo divino. Por lo tanto lo que dice Jacob "Vi a Dios cara a cara" se ha de referir no a

\footnotetext{
58 Delmar, F., El ojo espiritual: imagen y naturaleza en la Edad Media, Universidad Nacional Autónoma de México, México, 1993. p. 88.

59 Tomás de Aquino, Suma teológica, I. Tratado de Dios es uno, traducción de Francisco Barbado Viejo, Biblioteca de Autores Cristianos, Madrid, 2010 1, q.5 a3. (A partir de aquí STh)

60 "Ningún hombre puede ver la esencia de Dios si no está separado de esta vida mortal. La razón es porque, según hemos dicho, el modo de conocimiento es proporcionado al modo de ser del que conoce. Pues bien, mientras vivimos en este mundo, nuestra alma tiene su ser en una materia corporal, y por ello no conoce naturalmente más que las cosas cuya forma está en la materia o las qu mediante éstas puede concocer." STh, 1, q.12 a.11.

61 Tal capacidad es exclusiva del rapto o de la luz profética exclusiva de unos pocos.
} 
la esencia divina, sino a la figura en que Dios estaba representado. Por lo demás, el hecho de que se vea a Dios cuando habla, aunque la visión sea imaginaria, es una cualidad eminente de la luz profética. ${ }^{62}$

Pero si ello es así, la actitud de mera introspección y espera ya no se justifica, sino que el tiempo de la intimidad ha de dar paso a la curiosidad por la belleza del mundo y por las otras voces que han tratado acerca de él.

El mestizaje del que hemos hablado más arriba encuentra en Tomás de Aquino uno de sus ejemplos más claros. El dominico conoció, a través de la lectura las obras de los pensadores del periodo clásico grecorromano, el pensamiento de los presocráticos a los que se refirió con el apelativo de "filósofos de la naturaleza". Fuentes de su contacto con los que primero filosofaron fueron, principalmente, las obras de Platón y Aristóteles a las que dedicó gran parte de su esfuerzo intelectual. Sin embargo, su conocimiento no se limitó a la obra de los paganos que no conocieron las Escrituras sino que su curiosidad le hizo aproximarse sin ambajes al pensamiento de los autores árabes y judíos, herejes para la cristiandad. El aprecio que Tomás de Aquino sentía por la capacidad filosófica de Averroes lo convirtió, tal como señala Cruz Hernández ${ }^{63}$, en el primer autor latino "impresionado" por el Comentador. Esta admiración no se limitó a los textos que contenían el particular aristotelismo del pensador cordobés, sino que el Aquinate conoció y manejó con soltura gran parte del conjunto filosófico árabe disponible en sus días. ${ }^{64}$

Este aprecio por la obra de autores no cristianos fue impulsado por la concepción que el dominico tuvo de la sabiduría como labor estrechamente vinculada al conocimiento del mundo natural, -frente al noli foras ire agustiniano65-, y de la verdadera tarea del intelectual caracterizada por la obligación de instruirse y formarse 66 con ayuda del nuevo contexto universitario.

El estudio de la sabiduría es el más perfecto, sublime, provechoso y alegre de todos los estudios humanos. Más perfecto ciertamente, pues, el hombre en la medida en que se da al estudio de la sabiduría, posee ya de alguna forma la verdadera bienaventuranza. ${ }^{67}$

\footnotetext{
62 STh 1, q.12.a11.

63 Cfr. Cruz Hernández, M., "Santo Tomás y la primera recensión de Averroes por los latinos", Atti del Congresso Internazionale Tommaso d'Aquino nel suo settimo centenario, Edizione Dominicane italiane, Tomo 1: Le fonti del pensiero di S. Tommaso, Napoli, 1975. p.307.

${ }^{64}$ Cfr. Gómez Nogales, S., "Los árabes en la vida y en la doctrina de Santo Tomás" Op.cit. Atti del Congresso Internazionale Tommaso d'Aquino, pp. 334-340.

65Agustín de Hipona, Obras de San Agustín, IV, Obras apologéticas: De la verdadera religión, La Editorial Católica, Madrid, 1975. XXXIX, 72.

66 "Oportet igitur veritatem esse ultimum finem totius universi; et circa eius considerationem principaliter sapientiam insistere." Tomás de Aquino, Liber de veritate catholicae Fidei contra errores infidelium seu Summa contra Gentiles, t. 2-3. Ed. P. Marc, C. Pera, P. Caramello, Marietti, Taurini-Romae, 1961, I, 2. (A partir de ahora C.G.) I,2.

67 C.G. I, 1.
} 
Esta nueva forma de entender la naturaleza y su significado para la vida humana, vino a complementarse, en la obra del Aquinate con una teoría epistemológica de fuerte influjo aristotélico. Los sentidos - entendidos por Tomás de Aquino como vía principal de acceso al conocimiento- en su combinación con las abstracciones elaboradas por el entendimiento no pueden revelar al hombre la esencia de Dios, sino sólo venir a confirmar su existencia y su condición de creador.

Nuestro conocimiento natural tiene su principio en los sentidos, y por ello sólo puede alcanzar hasta donde pueda llevarle lo sensible. Lo sensible no puede elevar la inteligencia hasta ver la esencia divina, porque las criaturas sensibles son efectos que no se equiparan con el poder de su causa, por lo cual no es posible conocer con su auxilio todo el poder de Dios ni, por tanto, ver su esencia. Sin embargo, como son efectos suyos y de El dependen como de su causa pueden llevarnos a conocer la existencia de Dios y lo que necesariamente ha de tener en su calidad de causa primera de todas las cosas, que sobrepasa a cuanto produce. 68

Pero si ello era así, de nuevo, ya no tenía sentido la vieja teoría del simbolismo alegórico de lo corporal ni de su peligro desde el punto de vista moral. La belleza, la sensualidad y el atractivo de lo corpóreo dan muestra de la existencia de Dios de tal forma que su tratamiento intelectual lejos de desviar al hombre de sus deberes espirituales, lo mantiene en el camino de la creencia. Las imágenes y los cuerpos naturales son ahora signos de sí mismas y no símbolos, es decir, meras representaciones perceptibles de un significante oculto bajo su forma.

El conocimiento intelectual obtenido de imágenes, bien sean las recibidas de los sentidos por vía ordinaria, bien la formadas por Dios en la imaginación, es tanto más elevado cuanto en el hombre sea más intensa la luz intelectual, y por esto, merced a la infusión de la luz divina por la revelación, se obtiene mediante las imágenes sensibles un conocimiento más perfecto. 69

Frente a la posición de Bernardo de Claraval, destaca ahora la visión positiva ofrecida por Balubus a la colaboración entre arte y teología.

Sabed que tres razones han presidido la institución de las imágenes en la Iglesia. En primer lugar, para la instrucción de las gentes simples, puesto que ellos aprenden por las imágenes como nosotros aprendemos por los libros En segundo lugar, porque los misterios de la Reencarnación y los ejemplos de los santos pueden mejor influir en nuestra memoria al tenerlos cotidianamente a la vista. En tercer lugar, para provocar un senti-

\footnotetext{
68 STh, 1. q.12, a.12.
}

${ }^{69}$ STh, 1. q.12, a.13. 
miento de devoción que es más eficazmente excitado por medio de cosas vistas que por cosas oídas. 70

La expresión estética, gracias a esta reelaboración conceptual, no sólo pudo liberarse del complejo de inferioridad ontológica que hasta ahora había detenido su despliegue sino adoptar un protagonismo nunca conocido hasta entonces en la Europa medieval latina. El gótico elevó las catedrales hacia las alturas mostrando la unión entre la elevación intelectual y la apertura hacia el exterior. ${ }^{71}$ El propio cuerpo, del edificio y del ser humano, era ahora precisamente aquello que lo posibilita. El color, la representación realista, la riqueza formal y la complejidad estilística se abrieron paso en un optimismo deslumbrante. La luz exterior, física, corpórea comenzó a entrar a raudales a través de los inmensos vanos decorados con vidrieras de la misma forma que el saber de los antiguos inundaba la mente de los nuevos pensadores.

La mezcla entre lo pagano y lo cristiano dejó de ser motivo de sospecha para constituirse en la clave de bóveda de la construcción de una nueva cultura y el amor al mundo natural se plasmó con viveza en las obras artísticas de este siglo.

Sin embargo, podría parecernos que estas pocas figuras representan imperfectamente la riqueza del universo, y cabría acusar de impotencia y de timidez a los artistas del siglo XIII, si el mundo de las plantas y los animales tuviesen realmente en la catedral un lugar tan modesto. Pero basta levantar los ojos para ver la viña, el frambueso cargado de frutos y las largas ramas del rosal silvestre adheridos a las arquivoltas; algunos pájaros cantan entre las hojas de roble; otros están posados en los contrafuertes. Los animales de países lejanos: el león, el elefante, el camello y los indígenas la gallina, la ardilla, el conejo, alegran el basamento de las portadas. Monstruos, atados por sus alas de piedra, aúllan en las partes altas. Nuestros viejos maestros, los más ingenuamente apasionados que hubo jamás por las bellezas de la naturaleza, iqué poco merecen ese reproche de impotencia y de esterilidad! Sus catedrales no son sino vida y movimiento. ${ }^{72}$

Estas bellas palabras del gran historiador del arte medieval Émile Mâle nos transmiten de la forma más viva la plasmación estética de las ideas filosóficas ${ }^{73}$ que vertebraron el siglo XIII. Una nueva forma de estudiar y explicar el mundo -naturaliter- independiente en lo que respecta a su método, fuentes y autoridades, un

\footnotetext{
70 Iohannes Balbus, Summa grammaticalis quae vocatur Catholicon, Mainz, 1460. Text cit. en Delmar, F., El ojo espiritual: imagen y naturaleza en la Edad Media, Universidad Nacional Autónoma de México, México, 1993. p. 94.

${ }^{71}$ Chieffo Raguin, V., Brush, K. Draper, P., (eds) Artistic integration in gothic buildings, University of Toronto Press, Toronto, 2000. pp. 58-59

72 Mâle, E., El arte religioso del siglo XIII en Francia: El Gótico, Ediciones Encuentro, Madrid, 2001, p. 54.

73 Cfr Erlande-Brandenburg, A., El arte gótico, Akal, Madrid, 1993, p. 584.
} 
nuevo contexto político, institucional y educativo y una renovada atracción y curiosidad por la belleza natural vienen a explicar de qué modo el siglo XIII constituyó un cambio radical en las reglas de juego estéticas del pensamiento occidental.

Cualquiera que estudie, sin prejuicios, la fauna y la flora decorativas del siglo XIII no verá en ellas más que una obra de arte puro. Ninguna idea en este arte encantador, sino un tierno y profundo amor a la naturaleza. Los escultores medievales, entregados a sí mismos, no se preocupaban ya de símbolos: volvían a ser pueblo, miraban al mundo con ojos de niño. ${ }^{74}$

74 Op. cit. Mâle, E., El arte religioso del siglo XIII en Francia: El Gótico, p. 60. 